\title{
A Study on Preferential Factors Influencing Women Students for Higher Education Abroad with Special Reference to Bengaluru, Karnataka
}

\author{
S. Saranya* and K. A. Thanuja \\ Assistant Professor, Department of Commerce, Kristu Jayanti College, Bengaluru, Karnataka, India; \\ saranya88.siva@gmail.com
}

\begin{abstract}
Women empowerment can be possible only through educating women. A country like India needs such an empowerment leading to the economic development of the society. Many people in India especially from rural areas still believe that marriage is important than educating women. Currently, the trend is changing. The rate of women students in schools and colleges has tremendously increased. Even the parents of rural areas are ready to send their girl children to schools. It shows the change in the mindset of the people and the society. Pinnacle to this change is that many women students are going abroad to pursue their higher studies. Countries like Canada, UK, USA, New Zealand, etc. are offering attractive scholarships for students. This has increased the ratio of women students obtaining their Master's degree from foreign countries. This study mainly aims to identify the increasing trend of pursuing higher education abroad by women students.
\end{abstract}

Keywords: Economic Development, Education, Higher Studies and Scholarships

\section{Introduction}

People in India usually spend large amount of their income for the marriage of their daughters and less on their education. In rural areas, male domination is more. It is necessary to create a positive awareness among rural community, which will help them to understand the importance of educating their girl child. Recently, Government of India has taken major decision to improve the life style of women in the rural society. As a part of this, many schemes were introduced. Government of India has launched many programmes to empower the community of women. It includes BBBP Scheme (Beti Bachao Beti Padhao) which is mainly trying to create awareness about the decreasing sex ratio in India, Women helpline schemes (launched on 1 April 2015) etc. Study abroad has become the dream of student community. Attractive scholarships, part time job and education loan attract many students to do their higher studies in foreign universities. Hence, it is affordable for even a middle-income family to send their children abroad to pursue higher education. Recent trend shows that there is an increase in the number of women students seeking their higher studies abroad. In particular, students are desirous of enrolling in the courses like Masters in Business Administration, Engineering, and Biotechnology etc. Therefore, an attempt is made to analyze the increasing rate of women students seeking their higher studies abroad.

\section{Review of Literature}

Sundaram et al.,, stated that education has a major role on the empowerment of women as it improves the job opportunities and the level of income for women. Bhat ${ }^{2}$ asserted that education is the most powerful tool to change the position of a society, dilution of gender bias, and for participation in the government, panchayats and public matters to eliminate gender discrimination. Shettar ${ }^{3}$ exposed that education helps in women empowerment yielding growth in their family, society and in the country. Pckianathan et al., ${ }^{4}$ pointed out that women are capable of doing many things like men and education helps women to improve their skills and level of knowledge to find a decent means of income, financial freedom and better status in the society. Ghara ${ }^{5}$ revealed that the number of women entering into the area of higher education is increasing, leading to a holistic development of women. 


\section{Objectives of the Study}

- To examine the preferential factors influencing the female students to study abroad

- To know the difficulties faced by them while studying abroad

\section{Methodology}

Primary data was used in the study with the help of a well-structured questionnaire. Secondary data was also used taken from relevant journals and websites. The areas covered in the Bengaluru City included Nelamangala, Devanahalli and Hoskote. Totally 140 female students who pursued their studies overseas were involved in this study based on Convenience Sampling Method.

\section{Results and Discussion}

The source of awareness for studying abroad is analyzed by using Henry Garret Ranking Technique and the details are shown in Table 1.

It is understood from Table 1 that 'Friends/Relatives' was ranked as a first source of awareness with a score of 54.50 Garrett points. 'Parents' was ranked as a second source with a score of 52.60 Garrett points. 'Academic mentors' was ranked as a third source with a score of 52.48 Garrett points. 'Siblings' was ranked as a fourth source with a score of 51.57 Garrett points. 'Others like websites of educational institutions' was ranked as a fifth source with a score of 51.43 Garrett points.

Table 2 shows the most important factors influencing the women students to study abroad which are considered in the study. These factors are examined and grouped into significant factors by employing Factor Analysis.

Table 1. Source of Awareness for Studying Abroad

\begin{tabular}{|c|l|c|c|c|}
\hline S.No. & \multicolumn{1}{|c|}{ Source } & Total Score & Average & Rank \\
\hline 1 & Academic mentors & 59038 & 52.48 & III \\
\hline 2 & Friends/ Relatives & 61309 & 54.50 & I \\
\hline 3 & Siblings & 58016 & 51.57 & IV \\
\hline 4 & Parents & 59174 & 52.60 & II \\
\hline 5 & Others & 57861 & 51.43 & V \\
\hline
\end{tabular}

Source: Primary Data

Table 2. Factors Influencing Women Students to Study Abroad

\begin{tabular}{|c|l|}
\hline S.No. & \multicolumn{1}{|c|}{ Factors } \\
\hline 1 & I wish to get the exposure at international level in the field of education (EIL) \\
\hline 2 & I like to experience a new culture in the host country (ENC) \\
\hline 3 & I try to make myself more marketable to future employment (MFE) \\
\hline 4 & I think I can improve my communication skills (ICS) \\
\hline 5 & I like to enjoy the proud moment when others call me foreign return (EPF) \\
\hline 6 & I can meet diverse range of people to develop the network around the world (DNW) \\
\hline 7 & I wish to enjoy a better life style (BLS) \\
\hline 8 & Peers' influence made me to go abroad (PIA) \\
\hline 9 & I can earn and learn simultaneously in a better manner (ELS) \\
\hline 10 & Financial assistance in the form of scholarship attracted me to study abroad (FAS) \\
\hline 11 & The type of program which I want to enroll for is available only abroad (TPA) \\
\hline 12 & I go abroad to get social exposure (GSE) \\
\hline 13 & I can also learn to speak foreign language (LFL) \\
\hline 14 & I prefer abroad just to have an experience of living in a host country (ELH) \\
\hline 15 & I prefer to seek my qualification from universities of worldwide recognition (QWR) \\
\hline
\end{tabular}




\begin{tabular}{|c|l|}
\hline S.No. & \multicolumn{1}{|c|}{ Factors } \\
\hline 16 & Confidence level can be increased while going alone to study abroad (CLI) \\
\hline 17 & I will take utmost care in deciding the course and the university (UCC) \\
\hline 18 & I wish as to be independent and self-reliant (ISR) \\
\hline 19 & My parents have enough money to send me abroad for higher studies (PMH) \\
\hline 20 & Some kind of local contacts in the host country can give the feel of security (LFS) \\
\hline
\end{tabular}

\section{Source: Primary Data}

Table 2 exposes the various possible factors influencing women students to study abroad.

Table 3 reveals the results of KMO and Bartlett's Test which explains the suitability of factor analysis in the present study.

Table 3 shows the KMO test value at 0.760 and hence the correlation is satisfactory and therefore, the factor analysis is suitable for the present study.

\section{Table 3. KMO and Bartlett's Test}

\begin{tabular}{|l|l|l|}
\hline \multicolumn{2}{|l|}{$\begin{array}{l}\text { Kaiser-Meyer-Olkin Measure of Sampling } \\
\text { Adequacy }\end{array}$} & .760 \\
\hline \multirow{3}{*}{ Bartlett's Test of Sphericity } & Approx. chi-square & 2.497 \\
\cline { 2 - 3 } & DF & 946 \\
\cline { 2 - 3 } & Sig. & .000 \\
\hline
\end{tabular}

\section{Communalities}

The communalities of all the 20 variables are shown in Table 4 .

Table 4. Communalities

\begin{tabular}{|l|c|c|}
\hline & Initial & Extraction \\
\hline VAR00001 & 1.000 & .652 \\
\hline VAR00002 & 1.000 & .676 \\
\hline VAR00003 & 1.000 & .610 \\
\hline VAR00004 & 1.000 & .757 \\
\hline VAR00005 & 1.000 & .716 \\
\hline VAR00006 & 1.000 & .655 \\
\hline VAR00007 & 1.000 & .700 \\
\hline VAR00008 & 1.000 & .673 \\
\hline VAR00009 & 1.000 & .553 \\
\hline VAR00010 & 1.000 & .690 \\
\hline VAR00011 & 1.000 & .809 \\
\hline VAR00012 & 1.000 & .758 \\
\hline VAR00013 & 1.000 & .756 \\
\hline VAR00014 & 1.000 & .679 \\
\hline VAR00015 & 1.000 & .656 \\
\hline
\end{tabular}

\begin{tabular}{|l|c|c|}
\hline & Initial & Extraction \\
\hline VAR00016 & 1.000 & .749 \\
\hline VAR00017 & 1.000 & .764 \\
\hline VAR00018 & 1.000 & .698 \\
\hline VAR00019 & 1.000 & .702 \\
\hline VAR00020 & 1.000 & .718 \\
\hline
\end{tabular}

Table 4 displays the communalities of all the 20 variables which measure the quantum of variance a variable shares with all other variables. The Principal Component Analysis is used to extract the factors. The variances extracted by the factors are called Eigen values. The total variance by successive factors is shown in Table 5.

Table 5 shows that though there are 20 variables, only 5 factors can be extracted. It can be inferred that 20.795 percentage of variance is explained by factor 1 , 8.839 percentage of variance is explained by factor 2 , 6.451 percentage of variance is explained by factor $3,5.701$ percentage of variance is explained by factor 4 and 5.337 percentage of variance is explained by factor 5 . Hence, all the 5 and variables put together explain the variance to the extent of 47.123 per cent.

In order to identify the factors that meaningfully summarize the sets of closely related variables, the rotation of the matrix is done by using Varimax with Kaiser Normalization.

The common factors are determined and the factor score coefficient is calculated for all variables. The 20 variables are thus reduced to 5 factors. The details are shown in Table 6.

Factor- 1 comprises variables like 'I will take utmost care in deciding the course and the university', 'I wish to be independent and self-reliant' and 'I can earn and learn simultaneously in a better manner. Hence, these variables can be termed as 'Career Oriented Education'.

Factor- 2 includes variables like 'I wish to get the exposure at international level in the field of education', 'I like to experience a new culture in the host country', 'I try 
A Study on Preferential Factors Influencing Women Students for Higher Education Abroad with Special Reference to Bengaluru, Karnataka

Table 5. Total Variance Explained

\begin{tabular}{|c|c|c|c|c|c|c|c|c|c|}
\hline \multirow{2}{*}{ Component } & \multicolumn{3}{|c|}{ Initial Eigen values } & \multicolumn{3}{|c|}{$\begin{array}{c}\text { Extraction Sums of Squared } \\
\text { Loadings }\end{array}$} & \multicolumn{3}{|c|}{ Rotation Sums of Squared Loadings } \\
\hline & Total & $\begin{array}{c}\% \text { of } \\
\text { Variance }\end{array}$ & Cumulative \% & Total & $\begin{array}{c}\% \text { of } \\
\text { Variance }\end{array}$ & Cumulative \% & Total & $\begin{array}{c}\% \text { of } \\
\text { Variance }\end{array}$ & Cumulative \% \\
\hline 1 & 9.150 & 20.795 & 20.795 & 9.150 & 20.795 & 20.795 & 5.554 & 12.623 & 12.623 \\
\hline 2 & 3.889 & 8.839 & 29.634 & 3.889 & 8.839 & 29.634 & 3.359 & 7.635 & 20.257 \\
\hline 3 & 2.838 & 6.451 & 36.085 & 2.838 & 6.451 & 36.085 & 3.095 & 7.035 & 27.292 \\
\hline 4 & 2.509 & 5.701 & 41.786 & 2.509 & 5.701 & 41.786 & 2.645 & 6.011 & 33.303 \\
\hline 5 & 2.348 & 5.337 & 47.123 & 2.348 & 5.337 & 47.123 & 2.376 & 5.401 & 38.704 \\
\hline 6 & 1.782 & 4.050 & 51.174 & & & & & & \\
\hline 7 & 1.542 & 3.504 & 54.677 & & & & & & \\
\hline 8 & 1.487 & 3.380 & 58.058 & & & & & & \\
\hline 9 & 1.381 & 3.140 & 61.197 & & & & & & \\
\hline 10 & 1.279 & 2.907 & 64.104 & & & & & & \\
\hline 11 & 1.171 & 2.661 & 66.765 & & & & & & \\
\hline 12 & 1.065 & 2.421 & 69.186 & & & & & & \\
\hline 13 & .978 & 2.224 & 71.410 & & & & & & \\
\hline 14 & .955 & 2.171 & 73.581 & & & & & & \\
\hline 15 & .913 & 2.075 & 75.655 & & & & & & \\
\hline 16 & .819 & 1.862 & 77.517 & & & & & & \\
\hline 17 & .778 & 1.768 & 79.285 & & & & & & \\
\hline 18 & .693 & 1.575 & 80.860 & & & & & & \\
\hline 19 & .674 & 1.532 & 82.392 & & & & & & \\
\hline 20 & .605 & 1.375 & 83.768 & & & & & & \\
\hline
\end{tabular}

\section{Extraction Method: Principal Component Analysis}

\section{Table 6. Factor Definition}

\begin{tabular}{|l|l|}
\hline Variables & Factor Name \\
\hline I will take utmost care in deciding the course and the university (UCC) & Factor - 1 \\
Career Oriented Education
\end{tabular}




\begin{tabular}{|l|l|}
\hline Variables & Factor Name \\
\hline I can meet diverse range of people to develop the network around the world (DNW) & \\
\hline I wish to enjoy a Better Life Style (BLS) & Factor - 5 \\
\hline Peers' influence made me to go abroad (PIA) & Economic and Social Reasons \\
\cline { 1 - 1 } My parents have enough money to send me abroad for higher studies (PMH) & \\
\cline { 1 - 1 } Some kind of local contacts in the host country can give the feel of security (LFS) & \\
\cline { 1 - 2 } I prefer abroad just to have an experience of living in a host country (ELH) & \\
\hline
\end{tabular}

Table 7. Difficulties Faced by the Women Students Studying Abroad

\begin{tabular}{|l|l|c|c|c|}
\hline S.No. & Factors & Total Score & Average & Rank \\
\hline 1 & Cultural shock & 25774 & 51.55 & III \\
\hline 2 & Homesickness & 28370 & 56.74 & I \\
\hline 3 & Not so easy to adjust with food habits & 23923 & 47.85 & VII \\
\hline 4 & Language barriers & 25326 & 50.65 & IV \\
\hline 5 & Fear of safety & 27363 & 54.73 & II \\
\hline 6 & Financial constraints & 25261 & 50.52 & V \\
\hline 7 & Adopting the new educational methods & 24004 & 48.01 & VI \\
\hline
\end{tabular}

\section{Source: Primary Data}

to make myself more marketable to future employment', 'I think I can improve my communication skills' and 'I like to enjoy the proud moment when others call me foreign return'. Therefore, these can be termed as 'Better Life Style'.

Factor- 3 includes variables like 'Financial assistance in the form of scholarship attracted me to study abroad', 'The type of program which I want to enroll for is available only abroad', 'I go abroad to get social exposure' and 'I can also learn to speak foreign language. Therefore, these can be termed as 'Multiple Benefits'.

Factor- 4 includes variables like 'I prefer to seek my qualification from universities of worldwide recognition' and 'Confidence level can be increased while going alone to study abroad.'Therefore, these can be termed as 'Personality Enhancement'.

Factor- 5 includes variables like 'I can meet diverse range of people to develop the network around the world', 'I wish to enjoy a better life style', 'Peers' influence made me to go abroad,' 'My parents have enough money to send me abroad for higher studies', 'Some kind of local contacts in the host country can give the feel of security' and 'I prefer abroad just to have an experience of living in a host country'. Therefore, these can be termed as 'Economic and Social Reasons'.

The difficulties faced by the women students while studying abroad is ranked and analysed through Henry Garret ranking Technique and are shown in Table 7.
Table 7 reveals that 'Homesickness' was ranked as the first and foremost of all difficulties faced by women students studying abroad with a score of 56.74 Garrett points. 'Fear of safety' was ranked as a second difficulty faced with a score of 54.73 Garrett points. 'Cultural shock' was ranked as a third difficulty faced with a score of 51.55 Garrett points. 'Language barriers' was ranked as a fourth difficulty faced with a score of 50.65 Garrett points. 'Financial constraints' was ranked as a fifth difficulty faced with a score of 50.52 Garrett points. 'Adopting the new educational methods' was ranked as a sixth difficulty faced with a score of 48.01 Garrett points. 'Not so easy to adjust with food habits' was ranked as a seventh difficulty faced with a score of 47.85 Garrett points.

\section{Conclusion}

Education has become the most important part of everyone's life. It is a life enhancer as it brings a great respect for the society. The study has indicated that women students were positively influenced when they were given the opportunity to study overseas with scholarships, to grow in their career and experience better life style. At the same time, women students studying abroad have faced difficulties too in terms of homesickness, cultural shock, financial constraints and language barriers. However, the educational system is on the right path improving women's education to yield better status in the society in many ways. 


\section{References}

1. Sundaram MS, Sekar M, Subburaj A. Women Empowerment: Role of Education. International Journal in Management and Social Science. 2014; 2(12):76-85.

2. Bhat RA. Role of education in the empowerment of women in India. Journal of Education and Practice. 2015; 6(10):188-91.

3. Shettar RM. A study on issues and challenges of women empowerment in India. IOSR Journal of Business and Management. 2015; 17(4):13-19.

4. Pckianathan N, Anushree SM, Manjunatha B. The role of higher education in empowering Indian Women. International Journal of Health and Allied Science. 2016; 5(3):135-7. https://doi.org/10.4103/2278-344X.187791

5. Ghara T. Status of Indian women in higher education. Journal of Education and Practice. 2016; 7(34):58-64.
6. Shindu J. Women's Empowerment through Education. Abhinav Journal. 2012; 1(11):3.

7. Mahalinga. Women's Empowerment through Panchayat Raj Institutions. Indian Journal of Research. 2014; 3(3).

8. Suguna M. Education and women empowerment in India. International Journal of Multidisciplinary Research. 2011; $1(8)$.

9. Chibber B. Women and the Indian political process. Mainstream Weekly Journal. 2010; 48(18).

10. Bhat T. Women education in India need of the ever. Human Rights International Research Journal. 2014; 1:3.

11. Available from: http://www.usaid.gov/what-we-do/genderequality-and-womens-empowerment

12. Available from: http://www.abhinavjournal.com/images/ Arts_\&_Education/Nov12/1.pdf

13. Available from: http://shodhganga.inflibnet.ac.in:8080/jspui/ bitstream/10603/8562/9/09_chapter\%204.pdf 